\title{
A study of physiological responses during match play in Indian national kabaddi players
}

\author{
G L Khanna, P Majumdar, V Malik, T Vrinda, M Mandal
}

\begin{abstract}
Objective-To determine the physical and physiological profile of kabaddi players and the physiological demands of playing a kabaddi match.

Methods-Maximum aerobic capacity ( $\left.\dot{\mathrm{V}} \mathrm{O}_{2} \mathrm{max}\right)$, maximum ventilation ( $\left.\dot{\mathbf{V}}_{\mathbf{E}} \mathbf{m a x}\right), \mathbf{O}_{2}$ pulse, respiratory equivalent (RE), maximum heart rate, and $\mathrm{O}_{2}$ debt were assessed on 16 players. The somatotype of the players was calculated by the Heath and Carter method. Heart rate was monitored during a selection trial match on eight players who represented India in the Asian Games, 1994. From the playing heart rate, oxygen consumption $\left(\mathrm{VO}_{2}\right)$ was computed through a heart rate $v \dot{\mathrm{v}} \mathrm{O}_{2}$ regression equation. Maximum lactate was evaluated from the blood samples collected at the end of the match.
\end{abstract}

Results-The average heart rate and oxygen consumption during the match were 146.5(SD 9.25) beats $\mathrm{min}^{-1}$ and 2.25(0.59) litre $\mathrm{min}^{-1}$ respectively. During raiding the maximum heart rate attained varied from $162.4(11.3)$ to $177.4(4.2)$ beats $\mathrm{min}^{-1}$. Out of 40 min of match play a raider raided on average on $8.13(2.03)$ occasions. The average time per raid was $20.8(6.26)$ s. The match heart rate and oxygen consumption was $72.3-83.3 \%$ of the maximum heart rate, and $43.5-70.5 \%$ of $\dot{\mathbf{v}} \mathrm{O}_{2}$ max respectively. Maximum lactate at the end of the match was 6.13(2.53) mmol litre ${ }^{-1}$. Kabaddi players had the somatotype of 2.68-4.71-1.83, with absolute back strength of $175.0 \mathrm{~kg}$. $\dot{\mathrm{V}} \mathrm{O}_{2} \max$ and $\mathrm{O}_{2}$ debt were $3.59(0.36)$ litre $\mathrm{min}^{-1}[47.82(3.68) \mathrm{ml}$ $\left.\mathrm{kg}^{-1} \mathrm{~min}^{-1}\right]$ and $5.3(1.85)$ litres $\left(70 \mathrm{ml} \mathrm{kg}^{-1}\right)$ respectively.

Conclusions-Kabaddi is an intermittent sport. The rest pause during the game is sufficient for recovery. During raiding the main source of energy is anaerobic. (Br F Sports Med 1996;30:232-235)

Key terms: kabaddi; maximum aerobic capacity; oxygen debt; somatotype

Functional preparation by sportsmen and women depends on the physiological demands of their particular sport. An evaluation of the exercise responses of high level sports competitors during competition can form a sound basis for the players' systematic development. The demands of various sports disciplines have been extensively studied..$^{1-5}$ However, studies on the physiological demands of kabaddi are scanty ${ }^{6-8}$ Although there have been sporadic investigations, a systematic evaluation of the physiological demands of this sport have not yet been undertaken in an organised way, since up to now the sport has been confined to a few Asian countries and has not been included in any major international competitions such as the Asian Games. However, in 1986 the game was for the first time included in the Asian Games as a demonstration game. Subsequently, in the 1990 and 1994 Asian Games, five countries participated in the competition. European and erstwhile USSR countries have also recently begun to play the game.

Kabaddi is an outdoor game played on a soft natural soil field of $12.5 \times 10$ metres. The field is divided by a middle line into two equal halves. Seven players on each side participate, and the game is played into two halves of 20 minutes each, with an interval of five minutes.

The present study was carried out with the aim to determining the physiological requirements of kabaddi so that the selection and training of the players can be planned in a scientific and methodical way.

\section{Methods}

The study was conducted on 16 national kabaddi players attending the national camp at the Sports Authority of India, Southern Centre, in preparation for the Hiroshima Asian Games of 1994. The team won the gold medal.

Body fat percentage was calculated from skinfold thickness measured with a Harpenden caliper at four sites-biceps, triceps, subscapular, and suprailiac. To calculate body fat percentage, the formulas of Durnin and Rehman $^{9}$ and Siri ${ }^{10}$ were used. Somatotype was calculated by the Heath-Carter method. ${ }^{11}$ Back strength was measured with a back dynamometer. Cardiorespiratory variables such as oxygen consumption $\left(\dot{\mathrm{V}}_{2}\right)$, ventilation $\left(\dot{\mathrm{V}}_{\mathrm{E}}\right)$, and heart rate were measured during graded exercise on treadmill. ${ }^{12}$ Initial speed of the treadmill was $8 \mathrm{~km} \mathrm{~h}^{-1}$ with an inclination of $2 \%$ and thereafter the speed was increased by 2 $\mathrm{km} \mathrm{h}^{-1}$ after every 2 min until a plateau of $\mathrm{VO}_{2}$ was attained or the respiratory quotient (RQ) value went up to more than $1.1 .^{13}$ During the recovery phase the physiological variables were monitored until the oxygen consumption returned to normal resting level. Oxygen debt was calculated by the standard method described by Fox et al. ${ }^{14}$

The entire experiment was performed at a room temperature varying from $23-25^{\circ} \mathrm{C}$ with relative humidity varying between $50 \%$ and $60 \%$. 
Table 1 Morphological and physiological variables in Indian kabaddi players

\begin{tabular}{|c|c|}
\hline & Mean (SD) \\
\hline Age (years) & $27.00(2.80)$ \\
\hline Height (cm) & $175.00(4.80)$ \\
\hline Weight (kg) & $74.90(4.80)$ \\
\hline Body fat $(\%)$ & $14.13(2.26)$ \\
\hline Lean body mass $(\mathrm{kg})$ & $64.30(4.20)$ \\
\hline Endomorphy & $2.68(0.57)$ \\
\hline Mesomorphy & $4.71(0.50)$ \\
\hline Ectomorphy & $1.83(0.62)$ \\
\hline Back strength (kg) & $172.00(24.00)$ \\
\hline$\dot{\mathrm{V}} \mathrm{O}_{2} \max$ (litre $\min ^{-1}$ ) & $3.59(0.36)$ \\
\hline$\dot{\mathrm{V}} \mathrm{O}_{2} \mathrm{max}\left(\mathrm{ml} \mathrm{kg}^{-1} \mathrm{~min}^{-1}\right)$ & $47.82(3.68)$ \\
\hline$\dot{\mathrm{V}}_{\mathrm{E}} \max$ (litre $\min ^{-1}$ ) & $124.70(13.80)$ \\
\hline $\mathrm{O}_{2}$ debt (litre) & $5.30(1.85)$ \\
\hline $\mathrm{O}_{2}$ debt $\left(\mathrm{ml} \mathrm{kg}^{-1}\right)$ & $70.40(23.04)$ \\
\hline $\mathrm{O}_{2}$ pulse $\left(\mathrm{ml} \mathrm{beat}^{-1}\right)$ & $17.00(1.82)$ \\
\hline $\begin{array}{l}\text { Respiratory equivalent at } \mathrm{VO}_{2} \max \text { ( } 1.1 \text { of } \\
\mathrm{O}_{2}^{-1} \text { ) }\end{array}$ & $34.88(3.23)$ \\
\hline Maximum heart rate (beats $\min ^{-1}$ ) & $186.00(7.00)$ \\
\hline
\end{tabular}

The regression equation of $\mathrm{VO}_{2} v$ heart rate was calculated to estimate oxygen consumption indirectly from heart rate.

Heart rate monitoring in actual matchplay was done on eight players finally selected to represent India in 1994 Asian Games, with the help of a Sport Tester (PE-3000) (Polarelectro Oy, Finland). Data stored in the memory of the Sport Tester were downloaded to a computer and analysis was done using suitable software (Polar, Finland).

Blood samples were drawn from the finger tip using an automatic pricker. Blood samples were collected between two and four minutes after the end of the match into a heparinised tube containing fluoride and nitrite as preservative. The samples were analysed in a standardised automatic lactate analyser (Analox Instruments) within $30 \mathrm{~min}$ after collection.

\section{Results}

Morphometric and physiological characteristics are presented in table 1 . The mean height and body weight were found to be $175 \mathrm{~cm}$ and $74.9 \mathrm{~kg}$ respectively. Kabaddi players had a somatotype of 2.68-4.71-1.83. Maximum aerobic capacity $\left(\mathrm{V}_{2} \mathrm{max}\right)$ and anaerobic capacity $\left(\mathrm{VO}_{2}\right.$ debt) were found to be 3.59 litre $\mathrm{min}^{-1}$ and 5.3 litres respectively. The kabaddi players had the absolute back strength of $175.0 \mathrm{~kg}$.

Mean(SD) of the match heart rate and raiding heart rate, along with $\mathrm{O}_{2}$ consumption every $4 \mathrm{~min}$ through the match are presented in table 2 . The results are expressed both in absolute terms and as a percentage of the heart rate, to assess the extent to which the game taxes the circulatory system. The mean match heart rate in the first half varied from 132.9 to 149.0 beats $\mathrm{min}^{-1}$, that is, $72.3 \%$ to $79.9 \%$ of the maximum heart rate, while in the second half it varied from 143.5 to 158.0 beats $\mathrm{min}^{-1}$, that is, $77.2 \%$ to $83.3 \%$ of the maximum heart rate. The overall mean heart rate in the first half was 143.4(11.5) beats $\mathrm{min}^{-1}$ (76.8\% of maximum heart rate), while in the second half it was 149.5 (7.5) beats $\min ^{-1}(80.1 \%$ of the maximum heart rate), significantly higher than in the first half $(\mathrm{P}<0.01) . \mathrm{O}_{2}$ consumption during the match varied from 1.69 to 2.77 litre $\mathrm{min}^{-1}$ ( $43.5 \%$ to $70.5 \%$ of $\dot{\mathrm{V}}{ }_{2} \mathrm{max}$ ). In the first half the raiding heart rate varied from 162.4 to 177.1 beats $\mathrm{min}^{-1}$, that is, $87.2 \%$ to $95.0 \%$ of maximum heart rate. In the second half it varied from 167.8 to 177.4 beats $\mathrm{min}^{-1}$, that is, $90.0 \%$ to $95.2 \%$ of the maximum heart rate. During raiding, $\mathrm{O}_{2}$ consumption varied from 2.98 to 3.55 litre $\mathrm{min}^{-1}$ ( $76.8 \%$ to $90.6 \%$ of $\dot{\mathrm{V}} \mathrm{O}_{2} \max$ ).

The average heart rate over the whole match was $146.5(9.25)$ beats $\mathrm{min}^{-1}$, that is, $78.7 \%$ of the maximum heart rate (table 3 ).

The mean recovery heart rate and $\mathrm{O}_{2}$ consumption during the $5 \mathrm{~min}$ interval are presented in table 4 . The mean minimum heart rate attained in the fifth minute of recovery was $109.7(10.9)$ beats $\mathrm{min}^{-1}$.

The number of raids and the duration of each raid are presented in table 5. The mean maximum lactate accumulated after the match was $6.13(2.53) \mathrm{mmol}$ litre $^{-1}$ (table 5) and ranged from $2.8^{\prime}$ to $11.8 \mathrm{mmol}$ litre $^{-1}$. A comparison of maximum lactate of kabaddi players with other disciplines is presented in the figure.

\section{Discussion}

In our earlier investigation on the 1990 Asian Games gold medalist kabaddi team we reported that kabaddi players have an endomorphic-mesomorphic physique. ${ }^{8}$ The present group of players also had an endomorphic-mesomorphic physique (2.74.71-1.83). Significant differences were not observed in the mesomorphic and ectomorphic components of the somatotype between the 1990 team and the present team. However, the endomorphic component was significantly reduced $(P<0.01)$ in the present group. This was due to a significant decline in body fat during training (unpublished data). The mean age of this group was also same as the 1990 Table 2 Mean (SD) of game and raiding heart rate (percentage of maximum heart rate) along with $\left[\mathrm{O}_{2}\right.$ consumption (percentage of $\dot{V} \mathrm{O}_{2}$ max)] during
kabaddi match.

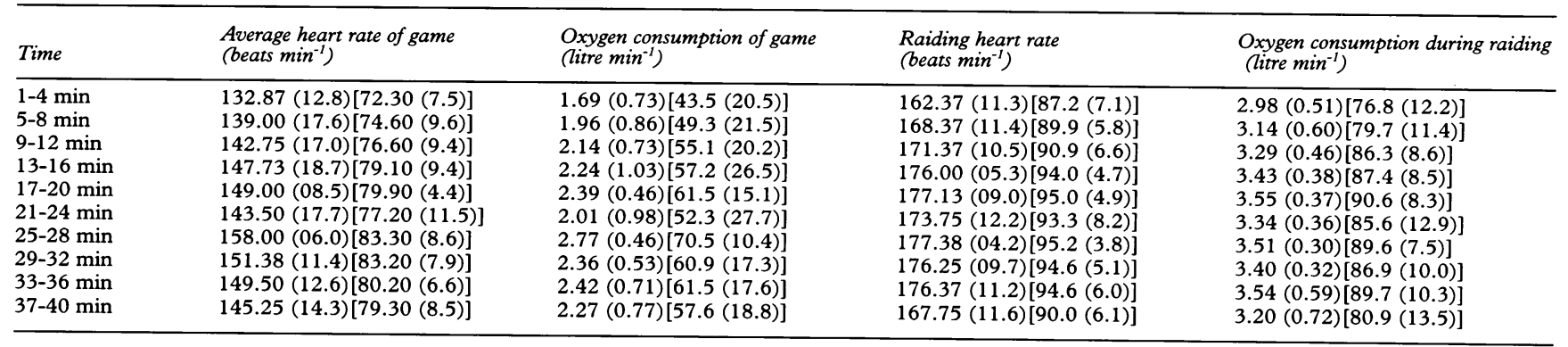


Table 3 Mean (SD) of game heart rate and $\mathrm{O}_{2}$ consumption during kabaddi match

\begin{tabular}{llrr}
\hline Variable & First half & \multicolumn{1}{c}{ Second half } & \multicolumn{1}{c}{ Total match } \\
\hline Heart rate (beats $\left.\min ^{-1}\right)$ & $143.40(11.50)$ & $149.50(7.5)$ & $146.50(9.25)$ \\
$\mathrm{O}_{2}$ consumption $\left(\right.$ litre $\left.\min ^{-1}\right)$ & $2.15(00.58)$ & $2.35(0.6)$ & $2.25(0.59)$ \\
\hline
\end{tabular}

group. This indicates that the higher percentage of body fat in the 1990 group $^{8}$ was not an effect of age but of a modification of body composition. The new rules of kabaddi stipulate that a player cannot participate in competition if his body weight is more than $80 \mathrm{~kg}$. Players have therefore regulated their body weight by controlling body fat content through diet and training. Lean body mass in the present group was higher by $2.1 \mathrm{~kg}$ than in the 1990 group. However, this difference was not statistically significant. The optimum body fat percentage for different sports disciplines varies from $6 \%$ to $15 \%$ in Indian sportspersons, ${ }^{15}$ except for heavyweight wrestlers and weightlifters. In kabaddi, excess body fat will hinder quick movement across the court, and the execution of explosive and agile movements and jumps. It will increase the energy expenditure in moving around the court. Back strength in the 1994 group was greater $[172.00(24.00) \mathrm{kg}]$ than in the 1990 group $[162.56(18.08) \mathrm{kg}]$. Improvement in lean body mass and a reduction in body fat has resulted in a trend to greater strength in the present group than in the 1990 group. The difference, however, was again not statistically significant. Greater strength in kabaddi players is helpful during raiding as well as in catching. A raider can push the catchers and make an escape more readily if he is physically stronger, and the same holds true for catching the raider.

The heart rate and $\mathrm{O}_{2}$ consumption response during match play have been employed as an index of the stress on the cardiorespiratory system. ${ }^{16}$ The average heart rate and $\mathrm{O}_{2}$ consumption attained in the match were 146.5 beats $\mathrm{min}^{-1}$ and 2.25 litre $\mathrm{min}^{-1}$ respectively. The average heart rate was lower than the threshold heart rate $\left[167.2(3.06)\right.$ beats $\left.\mathrm{min}^{-1}\right]$ and was $78.4 \%$ of the maximum heart rate.

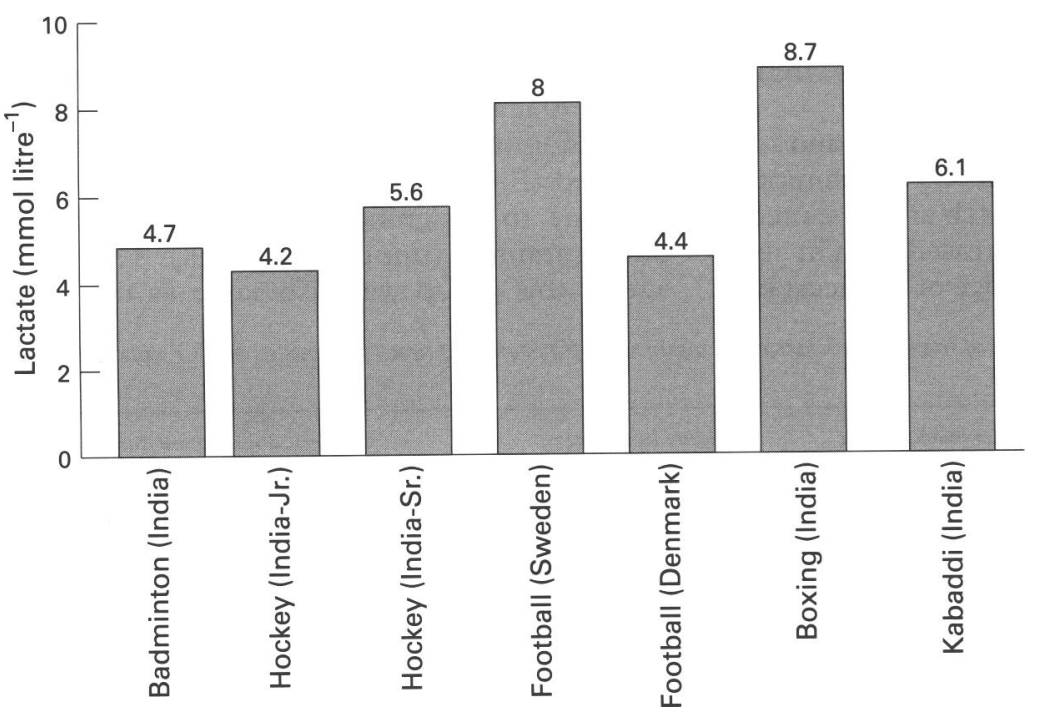

Figure 1 Comparison of maximum lactate in kabaddi players and in players of other sports.
Table 4 Mean (SD) of recovery heart rate and oxygen consumption during 5 minutes interval

\begin{tabular}{lll}
\hline Time & $\begin{array}{l}\text { Heart rate (beats } \\
\text { min }^{-1} \text { ) }\end{array}$ & $\begin{array}{c}\mathrm{O}_{2} \text { consumption } \\
\text { (litre } \text { min }^{-1} \text { ) }\end{array}$ \\
\hline 1st minute & $126.7(10.7)$ & $1.15(0.43)$ \\
2nd minute & $116.7(11.6)$ & $0.84(0.35)$ \\
3rd minute & $116.0(10.2)$ & $0.80(0.30)$ \\
4th minute & $111.0(8.0)$ & $0.62(0.33)$ \\
5th minute & $109.7(10.9)$ & $0.62(0.26)$ \\
\hline
\end{tabular}

Table 5 Mean (SD) of duration and number of raiding and maximum lactate after the end of the match

\begin{tabular}{lr}
\hline Variable & Mean (SD) \\
\hline Duration of raid (s) & $20.80(6.26)$ \\
Number of raids per match & $8.13(2.03)$ \\
Maximum lactate (mmol litre $\left.{ }^{-1}\right)$ & $6.13(2.53)$ \\
\hline
\end{tabular}

The average game heart rate is lower than in basketball ( 170 beats $\mathrm{min}^{-1}$ ), kayaking (176 beats $\left.\min ^{-1}\right)$, soccer $\left(165\right.$ beats $\left.\min ^{-1}{ }^{17}\right)$ and hockey $\left[157(15.1)\right.$ beats $\left.\mathrm{min}^{-1}\right]{ }^{2}$ It is comparable to the average heart rate of boxing (148 beats $\mathrm{min}^{-1}$ ) and canoe paddling (143 beats $\left.\min ^{-1}\right) .{ }^{17}$ However, the average heart rate of kabaddi is higher than volleyball $(110-125$ beats $\left.\min ^{-1}\right)$ and weightlifting (120-123 beats $\left.\mathrm{min}^{-1}\right) .{ }^{17}$ This game is of an intermittent type in which the players have time to recover; the pauses for rest in kabaddi are adequate for heart rate to fall by a notable extent. It is observed that out of 40 minutes of matchplay, a raider has to raid on an average of 8.13(2.03) occasions. The average time per raid was $20.8(6.26)$ seconds. The total time spent on raiding will be around 169 seconds per match. The rest of the time the player is involved in catching, holding, and locking the opponents and watching the raiding actions of his team mates. If a raider or a catcher is raided out/caught out, he has to stand out in the sitting block. It is clear that kabaddi players have sufficient time for recovery and the average heart rate during the match remains below the anaerobic threshold level. We found that in the first half and the second half the heart rate of the players remained below 130 beats $\mathrm{min}^{-1}$ for $4.94(3.21)$ minutes and 3.27(2.27) minutes respectively, that is, the heart rate remained below 130 beats $\mathrm{min}^{-1}$ for $24.7 \%$ of the time in the first half and for $16.3 \%$ of the time in second half. In total if five minutes of recovery time is included, then out of 45 minutes of play the heart rate of a player remains below 130 beats $\min ^{-1}$ for $29.3 \%$ of the total time. During the interval the average recovery heart rate after five minutes decreased to $109.7(10.9)$ beats $\mathrm{min}^{-1}$. During raiding the heart rate and $\mathrm{O}_{2}$ consumption attained varied from 162.4 to 177.4 beats $\mathrm{min}^{-1}$ and from 2.98 to 3.55 litre $\mathrm{min}^{-1}$ respectively, that is, $87.2 \%$ to $95.2 \%$ of the maximum heart rate and $76.8 \%$ to $90.6 \%$ of the $\mathrm{V}_{2} \max$, indicating that the dominant energy source during raiding is anaerobic, since the heart rate and $\dot{\mathrm{V}} \mathrm{O}_{2}$ max are above the anaerobic threshold level. During raiding, players do not take any breaths and have to perform intense spurts of explosive action - jumping, moving, and quick turning - into the opponents' lobby while con- 
tinuously chanting the word "kabaddi". During such activities the dominant energy source will be anaerobic. Anaerobic threshold estimation in a team game gives good insight into the relative dominance of aerobic and anaerobic demands. ${ }^{18}$

Lactate accumulation at the end of the match was $6.13 \mathrm{mmol}$ litre $^{-1}$. This is higher than in hockey $\left[5.6(2.0) \mathrm{mmol} \text { litre }^{-1}\right]^{2}$ and badminton $\left[4.7(1.9) \mathrm{mmol}\right.$ litre $\left.^{-1}\right]$ (unpublished data), but lower than in boxing ${ }^{19}$ and soccer $\left(8.0 \mathrm{mmol}\right.$ litre $\left.^{-1}\right){ }^{20}$ The high level of lactate can be attributed to the raiding component of the match.

The importance of aerobic-anaerobic capacity and other cardiorespiratory responses in kabaddi was explained in our earlier study. ${ }^{8}$ Aerobic-anaerobic capacity as well as other cardiorespiratory variables in the present group are comparable to the 1990 group. It can be inferred that about $48 \mathrm{ml} \mathrm{kg} \mathrm{min}^{-1}$ of $\dot{\mathrm{V}} \mathrm{O}_{2}$ max and 4-7 litres of $\mathrm{O}_{2}$ debt will be satisfactory for a kabaddi player to achieve Asian level. However, higher values will be advantageous.

\section{CONCLUSION}

From the present study it can be concluded that kabaddi is an intermittent type of game. The average heart rate attained during a match is 146 beats $\mathrm{min}^{-1}$. The rest pause during the game is sufficient to allow recovery to a marked extent. During raiding the main source of energy release is anaerobic. The maximum lactate accumulated at the end of the match is $6.13 \mathrm{mmol}^{\text {litre }} \mathrm{e}^{-1}$. To meet the demands of the match kabaddi players should have an endomorphic-mesomorphic physique (2.684.71-1.83) with body fat below $13 \%$. A $\dot{\mathrm{V}} \mathrm{O}_{2} \mathrm{max}$ of $48 \mathrm{ml} \mathrm{kg}^{-1} \mathrm{~min}^{-1}$ and an $\mathrm{O}_{2}$ debt of
$70.4 \mathrm{ml} \mathrm{kg}^{-1}$ will be satisfactory for a kabaddi player.

1 Khanna GL, Majumdar P, Malik V, Mandal M. Physiological demand of different positional players in women hockey match. Natl Inst Sports Scientific f 1995;18:5-14.

2 Ghosh AK, Goswami A, Majumdar P, Mathur DN. Heart rate and blood lactate response in field hockey players. Ind rate and blood lactate resp
7 Med Res 1991;94:351--6.

3 Reilly T, Borrie A. Physiology applied to field hockey. Sports Med 1992;14:10--26.

4 Mokha R, Sidhu LS, Kaur G, Singh J. Effect of training on weight and certain physiological parameters of Indian female hockey players with respect to their field position. $\mathcal{F}$ Sports Med Phys Fit 1990;30:377--81.

5 Malhotra MS, Ghosh AK, Khanna GL. Physical and physiological stresses of playing hockey on grassy and Astroturf fields. Society for National Institutes of Sports Fournal 1983;6: 13-20.

6 De AK, Debnath PK, Nagchaudhuri J. A comparison of physical efficiency between female volleyball and Kabaddi players. Natl Inst Sports Scientific f 1979;2:46--50

7 De AK, Debnath PK, Panda BK, Bhattacharya AK. Physical efficiency and tests on Indian male Kabaddi intercal efficiency and tests on Indian male Kabadd
university players. Br $₹$ Sports Med 1982;16:33--6.

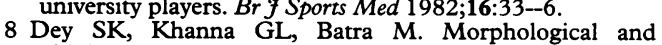
physiological studies on Indian national kabaddi players. $\mathrm{Br}$ f Sports Med 1993;27:237--42.

9 Durnin JVGA, Rehman MM. The assessment of the amount of fat in the human body from measurement of skinfold thickness. Br $\mathcal{F}$ Nutr 1967;21:681--9.

10 Siri WE. Body composition from fluid spaces and density. Report 19. Berkeley, California: University of California Press, 1956.

11 Heath BH, Carter JEL. A modified somatotype method. Am f Phys Anthropol 1967;27:57--74.

12 Shephard RJ. Tests of maximum oxygen intake-a critical review. Sports Med 1984;1:99-124.

13 Khanna GL. Aerobic, anaerobic capacities and cardiopulmonary responses to ergometry in children ranging in age from 8 to nary responses to ergometry in children ranging in age from 8

14 Fox EL, Robinson S, Weigman D. Metabolic energy sources during continous and interval running. $\mathcal{F}$ Appl Physiol 1969;27:174--8.

15 Sodhi HS, Sidhu LS. Physique and selection of sportsmen. $A$ kinanthropometric study. Patiala, India: Punjab Publishing House, 1984.

16 Astrand PO, Rodahl K. Textbook of work physiology. New York: McGraw-Hill, 1986

17 Reilly T, Secher N, Snell P, Williams C. Physiology of sports. New York: E \& F.N. Spon (imprint of Chapman and Hall), 1990.

18 Ghosh AK, Natraj HV, Joseph S. Physical demand of playing kho kho. NIS Scientific fै 1992;15:11-9.

19 Ghosh AK, Ahuza A, Goswami A, Majumdar P. Physical demand of boxing [abstr]. Ind 7 Med Res, 1992;95:75.

20 Ekblom B. Applied physiology of soccer. Sports Med 1986;3: 50-60. 